\title{
Changes in the levels of kynurenic acid and selected proinflammatory cytokines after pharmacological treatment and electroconvulsive therapy (ECT) in patients with depressive disorder
}

\author{
Zmiany poziomu kwasu kynureninowego i wybranych cytokin prozapalnych \\ u pacjentów z depresją leczonych farmakologicznie i za pomocą elektrowstrząsów (EW)
Marcin Olajossy ${ }^{1}$ A,B,D,G, Emilia Potembska ${ }^{2}$ C,D,E,F, Nikodem Skoczeń ${ }^{1}$ B,F, Bartosz Olajossy ${ }^{3}$ B,F, Ewa Urbańska ${ }^{3}$ B,F \\ $12^{\text {nd }}$ Department of Psychiatry and Psychiatric Rehabilitation Medical University of Lublin, Poland \\ ${ }^{2}$ Department of Psychiatric Nursing, Medical University of Lublin \\ ${ }^{3}$ Chair and Department of Experimental and Clinical Pharmacology, \\ Laboratory of Cellular and Molecular Pharmacology
}

\begin{abstract}
The aim of the present study was to compare the concentrations of KYNA, 3-OH-KYN and the cytokines TNF- $\alpha$ and IL-6 in patients with depression vs. healthy controls as well as in patients with depression treated pharmacologically vs. those treated using ECT. We also evaluated the relationship between the concentrations of KYNA, 3-OH-KYN and the cytokines TNF- $\alpha$ and IL- 6 and clinical improvement measured on the MADRS scale in patients treated pharmacologically and those treated with ECT.

Subjects and methods: The study group comprised 29 patients aged 28 to 60 years with a diagnosis of a major depressive episode. Eleven of the patients received pharmacological treatment and 18 were treated with ECT.

Patients were assayed for serum levels of KYNA and the cytokines IL- 6 and TNF- $\alpha$. Clinical improvement was measured on the MADRS depression rating scale and the clinical global impression (CGI) scale.

Results: Significant differences were found in KYNA levels between depressive patients and healthy controls. Pharmacological treatment significantly contributed to the increase in KYNA levels and ECT - to the increase in TNF- $\alpha$ levels in depressive patients.

Conclusions:

1. Depressive patients have significantly lower concentrations of KYNA than healthy individuals

2. Depressive patients who have undergone pharmacological treatment have significantly higher KYNA concentrations than before treatment.

3. Depressive patients who have undergone ECT treatment have significantly lower TNF- $\alpha$ concentrations than before treatment.

4. High pre-treatment levels of IL-6 are associated with a lower MADRS improvement index in pharmacologically treated patients with depression.
\end{abstract}

Keywords: kynurenic acid, depression, proinflammatory cytokines

\section{Streszczenie}

Celem pracy było porównanie stężenia KYNA, 3-OH-KYN oraz cytokin: TNF- $\alpha$ i IL-6 u pacjentów z depresją i osób zdrowych oraz u pacjentów z depresją leczonych farmakologicznie i EW. Oceniono również zależności między stężeniem KYNA, 3-OH-KYN oraz cytokin: TNF- $\alpha$ i IL-6 a wskaźnikiem poprawy w skali MADRAS w grupie pacjentów leczonych farmakologicznie i EW.

Grupa badana i metody: Grupę badaną stanowiło 29 pacjentów w wieku od 28 do 60 lat, z rozpoznaniem epizodu ciężkiej depresji. Farmakologicznie leczonych było 11 pacjentów, a u 18 osób stosowano elektryczną terapię drgawkową (EW).

U pacjentów oznaczano poziom kwasu KYNA oraz stężenie cytokin IL-6, TNF- $\alpha$ w surowicy krwi. W pracy zastosowano skalę depresji MADRAS oraz skalę ogólnego wrażenia klinicznego CGI.

Wyniki: Stwierdzono istotne różnice w zakresie stężenia KYNA między pacjentami a osobami zdrowymi. Leczenie farmakologiczne istotnie wpływa na wzrost stężenia KYNA, a EW na wzrost stężenia TNF- $\alpha$ u pacjentów z depresją.

Wnioski:

1. Pacjenci z depresją mają istotnie niższe stężenie KYNA niż osoby zdrowe.

2. Pacjenci z depresją po leczeniu farmakologicznym uzyskali istotnie wyższe stężenie KYNA niż przed leczeniem.

3. Pacjenci z depresją po leczeniu EW uzyskali istotnie niższe stężenie TNF- $\alpha$ niż przed leczeniem.

4. Wysoki poziom IL-6 przed leczeniem łączy się z mniejszym wskaźnikiem poprawy w skali MADRS u pacjentów z depresją objętych leczeniem farmakologicznym.

Słowa kluczowe: kwas kynureninowy, depresja, cytokiny prozapalne

(C) 2016 Medical University of Lublin. This is an open access article distributed under the Creative Commons Attribution-NonComercial-No Derivs licence (http://creativecommons.org/licenses/by-nc-nd/3.0/) 


\section{Introduction}

In recent years, a number of analyses have been conducted regarding changes in the immune system and changes related to enzyme activities along the kynurenine pathway in patients with mental disorders. Induction of indoleamine (2,3)-dioxygenase (IDO) by the proinflammatory cytokines IL- 6 and TNF- $\alpha$ has been shown to lead to a reduction in the concentration of tryptophan (TRP), the precursor of serotonin [1]. Dursun et al. [2] believe that the decrease in the concentration of TRP may have a depressogenic effect. This opinion [2] has been confirmed by studies in which patients with bipolar disorder [3] and women with post-partum blues [4] were found to have a lower tryptophan index, compared to healthy controls. Several studies [5-11] have shown that plasma levels of interleukin-6 (IL-6) are higher in depressive disorder patients than in healthy subjects. Hestad et al. [12] and Tuglu et al. [13] have observed significantly higher levels of TNF- $\alpha$ in patients with depression than in control groups. Moreover, it has been found that plasma levels of proinflammatory cytokines, such as IL- 6 and TNF- $\alpha$, are also increased in patients with depression associated with bipolar disorder, as compared to healthy individuals $[14,15]$. The concentrations of these cytokines, according to O’Brien et al. [14] and Moddabernia et al. [15] normalize during euthymia.

Results of some other studies indicate that there are no significant changes in the levels of proinflammatory cytokines in the course of depression. Kubera et al. [16] and Hocaoglu et al. [17] have found no significant differences in the plasma concentrations of IL- 6 between individuals with depression and those without depression. Hocaoglu et al. [17] have shown that the concentration of TNF- $\alpha$ in patients with depression does not differ significantly from the levels of this cytokine in a group of healthy individuals.

Authors dealing with depression also pay attention to the imbalance in the kynurenic acid pathway (KYNA) that occurs in this disease [18]. Myint et al. [19] have observed an increase in the activity of indoleamine 2,3-dioxygenase (IDO) in depressed patients compared to healthy subjects. Increased activation of IDO by proinflammatory cytokines in patients with depression leads to elevated production of the neurotoxic metabolites 3-hydroxykynurenine (3-OH-KYN) and quinolinic acid (QUIN), at the cost of KYNA synthesis [18,20-22]. Considering this fact, Myint and Kim [18] have arrived at the conclusion that depression is associated with disturbances of the balance in the kynurenine pathway involving dominant synthesis of the neurodegenerative quinolinic acid at the expense of the neuroprotective KYNA pathway. This observation has led the authors [18] to formulate a neurodegenerative hypothesis of depression. The theory of imbalance in the kynurenine pathway has also been confirmed by data obtained by the authors of $[3,23,24,25]$, who found statistically significantly lower levels of KYNA in the plasma of patients with depression compared to healthy subjects. The question of the importance of the glutamatergic system in the pathophysiology of psychiatric disorders has also been raised by Moghaddam et al. [26], who observed regional differences in the regulation of the NMDA and AMPA (alpha-amino-3-hydroxy-5-methyl-4isoxazolepropionic acid) receptors related to the release of dopamine in the prefrontal cortex compared with the striatum as well as changes in glutamate release in response to a topical application of selective NMDA antagonists such as AP5. This effect had been attributed by the researchers to local pre-synaptic mechanisms that autoregulated glutamate release; however, it was found later that pre-synaptic NMDA receptors were rare and did not play a critical role in the inhibition of glutamate release.

Numerous contemporary studies show that antidepressive treatment has an effect on the concentration of proinflammatory cytokines $[27,28]$. It was demonstrated in an animal model study that administration of mianserin to rats with experimentally induced depression resulted in a significant reduction in the concentrations of IL-6 and TNF- $\alpha$ [28]. Służewska et al. [29] observed reduced concentrations of IL- 6 in depressed patients undergoing treatment with fluoxetine compared to pretreatment values. Tuglu et al. [13] found a significant reduction in TNF- $\alpha$ levels in patients with depression during therapy with selective serotonin reuptake inhibitors (SSRI). In a study conducted by Basterzi et al. [30], it was demonstrated that in patients with major depression, a 6-week treatment with SSRI antidepressants caused a decrease in the level of IL- 6 compared to its pre-treatment level.

Lanquillon et al. [31] assessed the level of IL-6 and TNF- $\alpha$ in depressed patients before and after a 6-week treatment with amitriptyline. Response to treatment was assessed using the MADRS scale. Those authors [31] demonstrated that, in comparison to a control group, patients showing a good response to amitriptyline treatment had significantly lower levels of IL-6 before the onset of the therapy, while those poorly responsive to treatment had significantly higher levels of this cytokine prior to treatment. Post-treatment levels of Il- 6 were similar in both groups of patients. Pre-treatment levels of TNF- $\alpha$, on the other hand, were significantly higher both in the group of patients with a good and those with a poor response to treatment, compared to the control group. However, the post-treatment concentration of TNF- $\alpha$ decreased significantly only in the group of individuals with a good response to treatment, compared to the baseline [31]. On the basis of these results, Lanquillon et al. [31] have formulated a hypothesis that non-stimulated secretion of 
TNF- $\alpha$ is associated with a clinical improvement in patients, while the level of IL- 6 could dichotomize the patients into responders and non-responders already at admission. Eller et al. [27] showed that high pretreatment levels of TNF- $\alpha$ in depressed patients predisposed them to a lack of response to a 12 -week treatment with escitalopram (response or lack of response were measured using the MADRS scale).

Different results regarding the impact of pharmacological treatment on the levels of proinflammatory cytokines have been obtained by Kubera et al. [16] and Maes et al. [8]. After 6 weeks of pharmacological treatment of patients with depression, Kubera et al. [16] observed no significant changes in the concentrations of IL-6, despite a significant clinical improvement, as measured by the Hamilton scale. Similarly, Maes et al. [8] observed no statistically significant changes in the concentrations of IL-6 during treatment of depression with fluoxetine and tricyclic antidepressants.

While many publications are devoted to the influence of various antidepressants on the immune system, the effect of electroconvulsive therapy (ECT) on this system is still poorly understood. A study conducted by Hestad et al. [12], who evaluated long-term effects of ECT on the concentration of TNF- $\alpha$, showed that there was a significant decrease in plasma levels of TNF- $\alpha$ in patients with depression after a series of ECT sessions. In another study, Lehtimäki et al. [32] assessed the short-term effects (after 3 and 6 hours) of ECT on plasma levels of the cytokines. They observed an increased release of IL- 6 at 3 and 6 hours after ECT. The rapid increase in plasma levels of IL-6 after ECT correlated with the dose of electrical stimulus used, which, according to the authors of [32], was probably due to depolarization of neurons.

In the studies conducted so far, authors $[3,23]$ have also assessed the level of KYNA in depressive patients before and after antidepressant treatment. They have found no statistically significant increase in KYNA levels in the serum of patients after treatment with different antidepressants, relative to the pre-treatment baseline [3]. The results of an animal model study carried out by Kocki et al. [33] indicate that citalopram, fluoxetine and amitriptyline increase the ratio of kynurenic acid to 3-hydroxykynurenine. These investigators [33] have found that these antidepressants modulate the kynurenine pathway, and that their effects may be associated with the restoration of the beneficial KYNA /3-OH-KYN ratio.

In an extensive monograph, Olajossy [23] evaluated the impact of ECT on the level of KYNA in patients diagnosed with depression associated with recurrent depressive disorder and bipolar disorder with a major depressive episode. The author [23] found that the increase in
KYNA in the blood serum after ECT, compared to the baseline, was not statistically significant.

The aim of this present study was to answer the following research questions:

- if and what differences there are in the concentrations of KYNA, 3-OH-KYN and the cytokines TNF- $\alpha$ and IL-6 between depressed patients and healthy individuals?

- if and what differences there are in pre-treatment and post-treatment concentrations of KYNA, 3-OH-KYN and the cytokines TNF- $\alpha$ and IL- 6 between patients with depression treated pharmacologically and those treated using ECT?

- if and what relationships there are between the concentrations of KYNA, 3-OH-KYN and the cytokines TNF- $\alpha$ and IL- 6 and clinical improvement measured on the MADRS scale in patients treated pharmacologically and those treated with ECT?

\section{Subjects}

The study group comprised 29 in-patients of the Lublin Teaching Hospital aged 28 to 60 years, with a diagnosis of a major depressive episode with or without psychotic symptoms, according to ICD-10, in the course of recurrent depressive disorder of bipolar disorder. The patients had severe and very severe depression, as measured on the MADRS scale. Eleven patients were treated pharmacologically (six patients received escitalopram and five received escitalopram combined with mirtazapine) and 18 patients received electric convulsive therapy (ECT). The control group consisted of 15 healthy subjects, aged from 24 to 62 years. The study was approved by the Clinical Research Ethics Committee of the Medical University of Lublin (decision KE-0254/3/2006).

\section{Study procedure}

\section{The ECT procedure}

Patients were referred for ECT treatment in accordance with relevant procedures after they had given their informed consent, had undergone an ECG, an EEG and laboratory tests to assess their physical state, and had been consulted by a neurologist and an internist. In accordance with the accepted principles, in patients referred for ECT treatment, all drugs that significantly affected the seizure threshold were discontinued- this excluded the use of barbiturates, benzodiazepines, lithium and other mood-stabilizing drugs. The majority of the patients received antidepressants; most often they were treated with a monotherapy of SSRIs, as this method is considered to be both safe and effective [34]. This procedure was mostly a continuation of existing treatment. Recruitment of a "pure" group of patients who receive ECT treatment alone is difficult and may raise ethical objections. 
The therapeutic procedures for the application of ECT did not deviate from the standards recommended in Poland [34]. Bilateral ECT was performed using a Spectrum $500 \mathrm{Q}$ device at suggested stimulus doses, with the electrodes placed in the frontotemporal position. Anaesthetic premedication was given to patients to induce general anesthesia or muscle relaxation (injections of thiopental, succinylcholine and atropine). During premedication and after ECT, the patients were oxygenated. The treatment included 12 ECT sessions: 2 sessions per week.

\section{Methods}

$5.0 \mathrm{~mL}$ samples of native blood were drawn from the median cubital vein. After collecting, the blood was centrifuged for 15 minutes at $3500 \mathrm{rpm}$, and then the supernatant was collected and frozen at $-72^{\circ} \mathrm{C}$.

The content of KYNA acid in serum was assessed at the Department of Experimental and Clinical Pharmacology, Medical University of Lublin, using a Varian Pro Star 210 liquid chromatograph (California). Chemical reagents used for chromatographic evaluation of KYNA content in the test samples were from Baker BV (Deventer, the Netherlands). The supernatant was frozen using an Innova U101 ultra low temperature lab freezer. The material for analysis was prepared using a modified method by Turski et al. [35]. Measurements of KYNA content in the samples were based on the principle of high-performance liquid chromatography (HPLC).

The cytokines IL- 6 and TNF- $\alpha$ were determined in serum by ELISA (enzyme linked immunosorbent assay) using the commercially available kits: Human TNF-alpha Quantikine and Human IL-6 Quantikine from R\&D. Based on the light absorbances of sample wells and standard wells, a computer coupled to a plate reader plotted the calibration curves and then calculated the concentrations of TNF- $\alpha$ and IL- 6 in the test samples.

The severity of depressive disorders was assessed on the Montgomery-Asberg Depression Rating (MADRS) scale [36]. It is a seven-point scale for assessing depression (in particular the so-called endogenous type) which shows good agreement with other psychometric instruments for depression rating and is often used in clinical trials testing the effectiveness of treatment. Severity of depression according to MADRS score is as follows: 0-11 no depressive symptoms, 12-19 mild depression, 20-28 moderate depression, 29-43 severe depression, 44-60 very severe depression.

The Clinical Global Impression (CGI) scale was also used in this study.

\section{Statistical tests}

The results were analyzed statistically using STATISTICA 10.0PL software. Because the measurements were characterized by high skewness, results were presented as median, a measure of central tendency. Equality of distribution for each variable within normal distribution groups was tested using Lilliefors' version of the Kolmogorov-Smirnov test as well as the Shapiro-Wilk test. Because the test variables did not have a normal distribution, nonparametric tests were used for further analysis. These tests are resistant to deviations from the assumptions of normality of distribution and heterogeneity of variance in the groups compared. Pairs of independent variables were compared using the Mann-Whitney U test, whereas pairs of dependent variables were compared using the Wilcoxon test. The relationships between variables were analyzed using Spearman's $\rho$ non-parametric correlation.

\section{Results}

In the first stage of the study, the Mann-Whitney $U$ test was used to compare the concentrations of KYNA, $3-\mathrm{OH}-\mathrm{KYN}$ and the cytokines TNF- $\alpha$ and IL- 6 in the serum of patients prior to treatment and in the serum of control healthy subjects (Table 1). The concentrations of KYNA and 3-OH-KYN are expressed as nmol/l and the concentrations of TNF- $\alpha$ and IL- 6 are reported as pg/ml.

Table 1. Comparison of concentrations of KYNA, 3-OH-KYN and the cytokines TNF- $\alpha$ and IL- 6 in the blood plasma of depressed patients and healthy controls

\begin{tabular}{|l|c|c|c|c|}
\hline \multirow{2}{*}{ Variables } & $\begin{array}{c}\text { Control } \\
\text { Group }\end{array}$ & $\begin{array}{c}\text { Depressive } \\
\text { Patients }\end{array}$ & \multirow{2}{*}{$\mathrm{Z}$} & \multirow{2}{*}{$\mathrm{p}$} \\
\cline { 2 - 3 } & Median & Median & $\mathrm{Z}$ & \\
\hline KYNA & 9.45 & 3.15 & 3.67 & 0.001 \\
\hline 3-OH-KYN & 42.50 & 59.40 & -1.73 & 0.083 \\
\hline TNF- $\alpha$ & 109.97 & 72.85 & 1.20 & 0.273 \\
\hline IL-6 & 0.98 & 0.88 & 0.20 & 0.838 \\
\hline
\end{tabular}

The results of analyzes indicated that healthy individuals had significantly higher levels of KYNA than depressed patients before treatment. Patients before treatment did not differ statistically significantly from healthy individuals in the concentrations of $3-\mathrm{OH}-\mathrm{KYN}$ and the selected pro-inflammatory cytokines TNF- $\alpha$ and IL- 6 .

Table 2 shows the results of the Mann-Whitney U test, which was used to compare the concentrations of KYNA, 3-OH-KYN, TNF- $\alpha$ and IL- 6 between patients with depression referred for pharmacological treatment and those referred for ECT treatment.

Patients referred for pharmacological treatment did not differ statistically significantly in their baseline KYNA, and 3-OH-KYN, and TNF- $\alpha$ and IL-6 levels from patients referred for ECT treatment (table 2).

Table 3 presents the results of the Mann-Whitney $\mathrm{U}$ test, which compared the severity of depression, measured on the MADRS scale, and the general functioning of patients referred for pharmacological treatment and those referred for ECT treatment. 
Table 2. Comparison of concentrations of KYNA, 3-OH-KYN and the cytokines TNF- $\alpha$ and IL- 6 in the blood plasma of patients with depression referred for pharmacological treatment and those referred for ECT treatment

\begin{tabular}{|l|c|c|c|c|}
\hline Variables & $\begin{array}{c}\text { Patients } \\
\text { referred for } \\
\text { pharmacological } \\
\text { treatment }\end{array}$ & $\begin{array}{c}\text { Patients } \\
\text { referred } \\
\text { for ECT } \\
\text { treatment }\end{array}$ & \multirow{2}{*}{$\mathrm{Z}$} & \multirow{2}{*}{$\mathrm{p}$} \\
\cline { 2 - 3 } & Median & Median & $\mathrm{Z}$ & \\
\hline KYNA & 3.15 & 3.65 & -0.89 & 0.371 \\
\hline 3-OH-KYN & 63.80 & 40.76 & 1.23 & 0.217 \\
\hline TNF- $\alpha$ & 79.33 & 70.83 & 0.09 & 0.925 \\
\hline IL-6 & 1.04 & 0.71 & 0.02 & 0.981 \\
\hline
\end{tabular}

Table 3. Comparison of the severity of depression as measured on the MADRS scale and the general functioning of patients referred for pharmacological treatment and patients referred for ECT treatment

\begin{tabular}{|l|c|c|c|c|}
\hline Variables & $\begin{array}{c}\text { Patients referred } \\
\text { for pharmacological } \\
\text { treatment }\end{array}$ & $\begin{array}{c}\text { Patients } \\
\text { referred } \\
\text { for ECT } \\
\text { treatment }\end{array}$ & \multirow{2}{*}{$\mathrm{Z}$} & $\mathrm{p}$ \\
\cline { 2 - 5 } & Median & Median & $\mathrm{z}$ & \\
\hline CGI & 5.00 & 5.00 & 1.64 & 0.101 \\
\hline MADRS & 42.00 & 38.50 & 1.55 & 0.121 \\
\hline
\end{tabular}

Patients treated pharmacologically did not differ significantly from ECT patients in terms of severity of depression and overall functioning before starting the therapy.

Table 4 summarizes the results of the Wilcoxon test, which compares the severity of depression rated on MADRS and CGI before and after pharmacological and ECT treatments.

Table 4. Comparison of scores obtained by patients with depression on the MADRS and CGI scales before and after pharmacological treatment and ECT

\begin{tabular}{|l|l|c|c|c|c|}
\hline \multirow{2}{*}{ Variables } & $\begin{array}{c}\text { Patients } \\
\text { before } \\
\text { treatment }\end{array}$ & $\begin{array}{c}\text { Patients } \\
\text { after } \\
\text { treatment }\end{array}$ & & \\
\cline { 3 - 6 } & Median & Median & $\mathrm{Z}$ & $\mathrm{p}$ \\
\hline $\begin{array}{l}\text { Pharma- } \\
\text { cotherapy }\end{array}$ & CGI & 5 & 2 & 2.89 & 0.004 \\
\cline { 2 - 6 } & MADRS & 42 & 28 & 2.94 & 0.003 \\
\hline \multirow{2}{*}{ ECT } & CGI & 5 & 3.5 & 3.45 & 0.001 \\
\cline { 2 - 6 } & MADRS & 38.5 & 25 & 3.73 & 0.001 \\
\hline
\end{tabular}

The results indicate that patients who have undergone either pharmacological or ECT treatment have significantly lower scores on CGI and MADRS than before treatment, which means that patients perform better and have a lower level of depression after both types of treatment than before treatment.

Tables 5 and 6 show the results of the Wilcoxon test, which was carried out to compare the concentrations of KYNA, 3-OH-KYN and the cytokines TNF- $\alpha$ and IL- 6 in the blood plasma of patients with depression before and after pharmacological treatment or ECT
Table 5. Comparison of concentrations of KYNA,3-OH-KYN and the cytokines TNF- $\alpha$ and IL- 6 in the blood plasma of patients with depression before and after pharmacological treatment

\begin{tabular}{|l|c|c|c|c|}
\hline \multirow{2}{*}{ Variables } & $\begin{array}{c}\text { Patients before } \\
\text { pharmacological } \\
\text { treatment }\end{array}$ & $\begin{array}{c}\text { Patients after } \\
\text { pharmacological } \\
\text { treatment }\end{array}$ & \multirow{2}{*}{$\mathrm{N}$} & \multirow{2}{*}{$\mathrm{p}$} \\
\cline { 2 - 3 } & Median & Median & $\mathrm{Z}$ & \\
\hline KYNA & 3.15 & 4.30 & -2.19 & 0.028 \\
\hline 3-OH-KYN & 65.00 & 53.68 & 1.48 & 0.139 \\
\hline TNF- $\alpha$ & 74.04 & 77.66 & -0.05 & 0.959 \\
\hline IL-6 & 0.84 & 0.68 & 0.66 & 0.508 \\
\hline
\end{tabular}

The results of the analyzes indicate that pharmacologically treated patients had significantly higher levels of KYNA after treatment than before treatment. The concentration of 3-OH-KYN, TNF- $\alpha$ and IL-6 after pharmacological treatment did not differ significantly from their baseline levels before therapy.

Table 6. Comparison of concentrations of KYNA, 3-OH-KYN and the cytokines TNF- $\alpha$ and IL- 6 in the blood plasma of patients with depression before and after ECT

\begin{tabular}{|l|c|c|c|c|}
\hline \multirow{2}{*}{ Variables } & $\begin{array}{c}\text { Patients } \\
\text { before ECT }\end{array}$ & $\begin{array}{c}\text { Patients } \\
\text { after ECT }\end{array}$ & \multirow{2}{*}{} & \multirow{2}{*}{} \\
\cline { 2 - 3 } & Median & Median & $\mathrm{z}$ & $\mathrm{p}$ \\
\hline KYNA & 3.45 & 3.80 & -0.22 & 0.826 \\
\hline 3-OH-KYN & 65.07 & 95.60 & -1.73 & 0.084 \\
\hline TNF- $\alpha$ & 89.71 & 50.43 & 2.17 & 0.030 \\
\hline IL-6 & 1.20 & 1.09 & 0.47 & 0.638 \\
\hline
\end{tabular}

Patients treated with ECT had significantly lower posttreatment levels of TNF- $\alpha$ compared to the pre-treatment levels of this cytokine.

In the final phase of the study Spearman's $\rho$ correlation coefficients were calculated, which served as a basis for determining the relationship between pre-treatment and post-treatment concentrations of KYNA, 3-OH-KYN, TNF- $\alpha$ and IL- 6 in patients and an improvement index defined as post-treatment reduction from baseline in MADRS total score (Table 7).

Table 7. Relationships between concentrations of KYNA, 3-OH-KYN, TNF- $\alpha$ and IL-6 and MADRS improvement before and after pharmacological treatment or ECT

\begin{tabular}{|l|l|c|c|}
\hline \multicolumn{2}{|c|}{} & \multicolumn{2}{|c|}{ MADRS improvement } \\
\cline { 3 - 4 } \multicolumn{2}{|c|}{} & Pharmacotherapy & ECT \\
\hline \multirow{2}{*}{ KYNA } & Pre-treatment & -0.02 & 0.45 \\
\cline { 2 - 4 } & Post-treatment & -0.49 & 0.28 \\
\hline \multirow{2}{*}{$3-O H-K Y N$} & Pre-treatment & -0.12 & 0.01 \\
\cline { 2 - 4 } & Post-treatment & -0.57 & -0.01 \\
\hline \multirow{2}{*}{ TNF- $\alpha$} & Pre-treatment & 0.04 & 0.12 \\
\cline { 2 - 4 } & Post-treatment & 0.12 & 0.09 \\
\hline \multirow{2}{*}{ IL-6 } & Pre-treatment & $-\mathbf{0 . 6 4}^{*}$ & 0.16 \\
\cline { 2 - 4 } & Post-treatment & -0.28 & -0.17 \\
\hline
\end{tabular}

${ }^{*} \mathrm{p}<0.05 ;{ }^{* *} \mathrm{p}<0.01 ;{ }^{* * *} \mathrm{p}<0.001$ 
A statistically significant negative correlation between the concentration of IL-6 and MADRS improvement was observed, which showed that a high pre-treatment level of IL-6 was associated with a lower improvement index in pharmacologically treated patients. This relationship showed a high level of significance [37].

\section{Results and Discussion}

The analyses conducted in this paper show that healthy individuals have significantly higher levels of KYNA than depressive patients before treatment. In patients who have undergone a pharmacotherapy, a statistically significant increase in KYNA levels was observed, compared to pretreatment concentrations. In ECT patients, on the other hand, post-treatment concentrations of KYNA were only slightly higher than pre-treatment KYNA levels.

The results described in this present study are fully consistent with the observations of Olajossy [23], Olajossy et al. [25], Myint et al. [3] and Maes et al. [24], who found that KYNA levels in the plasma of patients with depression were statistically significantly lower than in healthy subjects. The present results also correspond with the results of an animal model study carried out by Kocki et al. [33] who found that citalopram, fluoxetine and amitriptyline enhanced KYNA concentration and increased the ratio of kynurenic acid to 3-hydroxykynurenine. Those investigators [33] found that the antidepressants they examined modulated the kynurenine pathway, and that their effects may have been associated with the restoration of the beneficial KYNA/OH-KYN ratio. The results obtained here stand in contrast to the observations of Myint and colleagues [3], who have found no statistically significant increase in KYNA levels in the serum of patients after treatment with different antidepressants, relative to the pre-treatment baseline. According to Olajossy [23] the increase in KYNA in the blood serum of patients after ECT, compared to the baseline is not statistically significant.

In terms of the concentration of $\mathrm{OH}-\mathrm{KYN}$, patients before treatment did not differ significantly from healthy individuals. Pharmacologically treated patients had slightly lower levels of 3-OH-KYN, and those treated with ECT - slightly higher concentrations of 3-OH-KYN than before treatment.

Kocki et al. [33], in an animal model study, observed a significant reduction in the synthesis of 3-OH-KYN in rat glial cell cultures under the influence of the administration of antidepressants (citalopram, fluoxetine and amitriptyline).

The results of the present study show that there are no differences in serum concentrations of the proinflammatory cytokines TNF- $\alpha$ and IL- 6 between depressed patients and healthy individuals. After ECT treatment, the concentrations of TNF- $\alpha$ in patients decreased significantly compared with pre-treatment concentrations. Pharmacological treatment did not significantly modify the levels of TNF- $\alpha$ in patients with depression.

The present results correspond closely with the results of Kubera et al. [16] and Hocaoglu et al. [17], who found no significant differences in the plasma concentrations of IL-6 between individuals with depression and those without depression. Hocaoglu et al. [17] showed that the concentrations of TNF- $\alpha$ in patients with depression did not differ significantly from TNF- $\alpha$ levels in a group of healthy individuals. Contrasting results were obtained by Hestad et al. [12], Lanquillon et al. [31] and Tuglu et al. [13], who observed significantly higher levels of TNF- $\alpha$ in patients with depression than in control groups. Similarly, O'Brien et al. [14] and Moddabernia et al. [15] found that patients with depression in bipolar disorder showed increased plasma levels of proinflammatory cytokines, such as IL- 6 and TNF- $\alpha$, as compared to a group of healthy subjects. Our study does not confirm the data showing that the levels of IL-6 in patients with depressive disorders are higher than in healthy individuals [5-11]. The results obtained in our study also differ from the observations of researchers who believe that treatment with mianserin [28], amitriptyline [31] and SSRI [13] reduces the concentration of TNF- $\alpha$ in patients with depression, compared to its pre-treatment values .

Our results indicating that there is a statistically significant reduction in plasma levels of TNF- $\alpha$ after the application of ECT are fully consistent with the results obtained by Hestad et al. [12], who evaluated long-term effects of ECT on the concentration of TNF- $\alpha$, showing that there was a significant decrease in plasma levels of TNF- $\alpha$ in patients with depression after a series of ECT sessions. On the basis of the results obtained in these studies, it can be concluded that the distant immunomodulatory effects of ECT consisting in reducing the level of TNF- $\alpha$ may be used as one of the elements of antidepressant therapy.

Our results show that, compared with pretreatment levels, the concentrations of IL-6 did not change significantly following treatment either in patients treated pharmacologically or those undergoing ECT. The results also point to a significant relationship between high levels of IL-6 prior to pharmacotherapy and a lower MADRS improvement.

The results reported in this present study correspond with the observations of Kubera et al. [16] who, after 6 weeks of pharmacological treatment of depressed patients found no significant changes in the concentrations of IL-6, despite significant clinical improvement in depression symptoms, measured on the Hamilton scale. Similarly, Maes et al. [8] did not observe statistically significant changes in the concentrations of IL-6 during treatment of depression with fluoxetine and tricyclic antidepressants. Our results do not confirm the results 
obtained by Basterzi et al. [30], who demonstrated that in patients with major depression, a 6-week treatment with SSRI antidepressants caused a decrease in the levels of IL6 compared to its pre-treatment levels and compared to healthy individuals.

The results obtained in our study indicate that the concentration of IL- 6 does not change as a result of the application of ECT; however, future studies should pay attention to how the levels of this cytokine change a few hours after ECT, as Lehtimäki et al. [32] demonstrated that there was an increased release of IL- 6 at 3 and 6 hours after ECT, and that the rapid increase in plasma levels of IL- 6 after ECT correlated with the dose of electrical stimulus.

Our findings, which show that a high pretreatment level of IL-6 is associated with a lower MADRS improvement index are consistent with the results obtained by Lanquillon et al. [31], who demonstrated that, in comparison to a control group, patients showing a good response to amitriptyline treatment had significantly lower levels of IL- 6 before the onset of the therapy, while those poorly responsive to treatment had significantly higher pre-treatment levels of this cytokine. On the basis of these results, Lanquillon et al. [31] formulated the hypothesis that pre-treatment levels of IL- 6 could dichotomize patients into responders and non-responders already at admission.

The present study obviously has some limitations, the major one being the relatively small number of subjects enrolled in the study (pharmacological and electroconvulsive therapy). The results probably require confirmation in a larger group of patients.

\section{Conclusions}

On the basis of the results obtained in the present study, the following conclusions were formulated:

1. Depressive patients have significantly lower concentrations of KYNA than healthy individuals

2. Depressive patients who have undergone pharmacological treatment have significantly higher KYNA concentrations than before treatment.

3. Depressive patients who have undergone ECT treatment have significantly lower TNF- $\alpha$ concentrations than before treatment.

4. High pre-treatment levels of IL-6 are associated with a lower MADRS improvement index in pharmacologically treated patients with depression.

\section{Conflict of interest}

The authors have declared no conflict of interest.

\section{Acknowledgment}

This study was supported by the grants from Medical University in Lublin, DS 186.

\section{References:}

1. Heyes MP, Saito K, Crowley JS, Davis LE, Demitrack MA, Der M. i wsp. Quinolinic acid and kynurenine pathway metabolism in inflammatory and non-inflammatory neurological disease. Brain 1992; 115: 1249-1273.

2. Dursun SM, Blackburn JR, Kutcher SP. An exploratory approach to the serotonergic hypothesis of depression: bridging the synaptic gap. Med. Hypotheses 2001; 56(2): 235-243.

3. Myint AM, Kim YK, Verkerk R, Scharpe S, Steinbusch H, Leonard B. Kynurenine pathway in major depression: evidence of impaired neuroprotection. J. Affect. Disord. 2007; 98(1-2): 143-151.

4. Kohl C, Walch T, Huber R, Kemmler G, Neurauter G, Fuchs D i wsp. Measurement of tryptophan, kynurenine and neopterin in women with and without postpartum blues. J Affect Disord. 2005; 86(2-3): 135-142.

5. Alesci S, Martinez PE, Kelkar S, Ilias I, Ronsaville DS, Listwak SJ i wsp. Major depression is associated with significant diurnal elevations in plasma interleukin-6 levels, a shift of its circadian rhythm, and loss of physiological complexity in its secretion: clinical implications. J. Clin. Endocrinol. Metab. 2005; 90: 2522-2530.

6. Ryś A, Miodek A, Szemraj P, Szemraj J, Kocur J. Interleukina-6 - jej funkcje, wpływ na zaburzenia nastroju i inne procesy chorobowe. Post. Psychiatr. Neurol. 2007: 16(4): 331-334.

7. Służewska A, Rybakowski J, Sobieska M. Aktywacja układu immunologicznego w depresji endogennej. Psychiatr. Pol. 1996; 30(5): 771-782.

8. Maes, M, Meltzer H, Bosmans E, Bergmans R, Vandoolaeghe E, Rajan R i wsp. Increased plasma concentrations of interleukin-6, soluble interleukin-6 receptor, soluble interleukin- 2 receptor and transferrin receptor in major depression. J. Affect. Disord. 1995; 34(4): 301-309.

9. Yoshimura R, Umene-Nakano W, Hoshuyama T, Ikenouchi-Sugita A, Hori H, Katsuki A i wsp. Plasma levels of brain-derived neurotrophic factor and interleukin- 6 in patients with dysthymic disorder: comparison with age- and sex-matched major depressed patients and healthy controls. Hum. Psychopharmacol. 2010; 25(7-8): 566-569.

10. Crnković D, Buljan D, Karlović D, Krmek M. Connection between inflammatory markers, antidepressants and depression. Acta Clin. Croat. 2012; 51(1): 25-33.

11. Dunjic-Kostic B, Ivkovic M, Radonjic NV, Petronijevic ND, Pantovic M, Damjanovic A i wsp. Melancholic and atypical major depressionconnection between cytokines, psychopathology and treatment. Prog. Neuropsychopharmacol. Biol. Psychiatry 2013; 43: 1-6.

12. Hestad KA, Tønseth S, Støen CD, Ueland T, Aukrust P. Raised plasma levels of tumor necrosis factor alpha in patients with depression: normalization during electroconvulsive therapy. J ECT. 2003; 19(4):183-188.

13. Tuglu C, Kara SH, Caliyurt O, Vardar E, Abay E. Increased serum tumor necrosis factor-alpha levels and treatment response in major depressive disorder. Psychopharmacology (Berl). 2003; 170(4): 429-433.

14. O'Brien SM, Scully P, Scott LV, Dinan TG. Cytokine profiles in bipolar disorder: focus on acutely ill patients. J. Affect. Disord. 2006; 90(2-3): 263-267.

15. Modabbernia A, Taslimi S, Brietzke E, Ashrafi M. Cytokine alterations in bipolar disorder: a meta-analysis of 30 studies . Biol. Psychiatry 2013; 74(1): 15-25.

16. Kubera M, Kenis G, Bosmans E, Zięba A, Dudek D, Nowak G i wsp. Plasma levels of intraleukin-6, intraleukin-10, and intraleukin-1 receptor antagonist in depression: comparison between the acute state and after remission. Pol. J. Pharmacol. 2000; 52(3): 237-241. 
17. Hocaoglu C, Kural B, Aliyazıcıoglu R, Deger 0, Cengiz S. IL-1 $\beta$, IL-6, IL-8, IL-10, IFN- $\gamma$, TNF- $\alpha$ and its relationship with lipid parameters in patients with major depression. Metab. Brain Dis. 2012; 27(4): 425-430.

18. Myint AM, Kim YK. Cytokine-serotonin interaction through IDO: a neurodegeneration hypothesis of depression. Med. Hypotheses 2003; 61(5-6): 519-525.

19. Myint AM, Bondy B, Baghai TC, Eser D, Nothdurfter C, Schule C i wsp. Tryptophan metabolism and immunogenetics in major depression: a role for interferon-gamma gene. Brain Behav Immun 2013 31: 128-133.

20. Ball HJ, Yuasa HJ, Austin CJ, Weiser S, Hunt NH. Indoleamine 2,3-dioxygenase-2; a new enzyme in the kynurenine pathway. Int. J. Biochem. Cell Biol. 2009; 41: 467-471.

21. Maes M, Verkerk R, Bonaccorso S, Ombelet W, Bosmans E, Scharpé S. Depressive and anxiety symptoms in the early puerperium are related to increased degradation of tryptophan in to kynurenine, a phenomenon which is related to immune activation. Life Sci. 2002; 71(16): 1837-1848.

22. Wichers $M$, Maes $M$. The role of indoleamine 2,3 dioxygenase (IDO) in the pathophysiology of interferon-alpha-induced depression. J. Psychiatry Neurosci. 2004; 29(1): 11-17.

23. Olajossy M. Poziom kwasu kynureninowego w surowicy chorych na depresję leczonych elektrycznie. Rozprawa habilitacyjna. Lublin: Uniwersytet Medyczny w Lublinie; 2010.

24. Maes M, Gałecki P, Verkerk R, Rief W. Somatization, but not depression, is characterized by disorders in the tryptophan catabolite (TRYCAT) pathway, indicating increased indoleamine 2,3-dioxygenase and lowered kynurenine aminotransferase activity. Neuro. Endocrinol. Lett. 2011; 32(3): 264-273.

25. Olajossy M, Olajossy B, Potembska E, Skoczeń N, Wnuk S, Urbańska E. Stężenie kwasu kynureninowego i wybranych cytokin podczas leczenia przeciwdepresyjnego. Neuropsychiatria i Neuropsychologia 2014; 9(2): 1-7.

26. Moghaddam B, Krystal JH Capturing the Angel in "Angel Dust": Twenty Years of Translational Neuroscience Studies of nmda Receptor Antagonists in Animals and Humans, Schizophr Bull (2012) 38 (5): 942-949

27. Eller T, Vasar V, Shlik J, Maron E. Pro-inflammatory cytokines and treatment response to escitalopram in major depressive disorder. Prog. Neuropsychopharmacol. Biol. Psychiatry 2008; 32(2): 445-450.

28. Manikowska K, Mikołajczyk M, Mikołajczak PŁ, BobkiewiczKozłowska T. The influence of mianserin on TNF- $\alpha$, IL- 6 and IL10 serum levels in rats under chronic mild stress. Pharmacol Rep. 2014; 66(1): 22-27.
29. Służewska A, Rybakowski JK, Laciak M, Mackiewicz A, Sobieska M, Wiktorowicz K. Interleukin-6 serum levels in depressed patients before and after treatment with fluoxetine. Ann. NY Acad. Sci. 1995; 762: 474-476.

30. Basterzi AD, Aydemir C, Kisa C, Aksaray S, Tuzer V, Yazici Ki wsp. IL-6 levels decrease with SSRI treatment in patients with major depression. Hum. Psychopharmacol. Clin. Exp. 2005; 20(7): 473-476.

31. Lanquillon S, Krieg JC, Bening-Abu-Shach U, Vedder H. Cytokine production and treatment response in major depressive disorder. Neuropsychopharmacology 2000; 22(4): 370-379.

32. Lehtimäki K, Keränen T, Huuhka M, Palmio J, Hurme M, Leinonen E i wsp. Increase in plasma proinflammatory cytokines after electroconvulsive therapy in patients with depressive disorder. J ECT. 2008; 24(1): 88-91.

33. Kocki T, Wnuk S, Kloc R, Kocki J, Owe-Larsson B, Urbańska EM. New insight into the antidepressants action: modulation of kynurenine pathway by increasing the kynurenic acid/3-hydroxykynurenine ratio. J. Neural. Transm. 2012;119(2): 235-243.

34. Zyss T. elektrowstrząsy: wprowadzenie do bioelektrycznej natury zaburzeń depresyjnych. Warszawa: Elmico; 2009.

35. Turski WA, Gramsbergen JB, Traitler H, Schwarcz R. Rat brain slices produce and liberate kynurenic acid upon exposure to L-kynurenine. J. Neurochem. 1989; 52: 1629-1636.

36. Montgomery SA, Asberg M. A new depression scale designed to be sensitive to change. Br. J. Psychiatry 1979; 134: 382-389.

37. Stanisz A. Przystępny kurs statystyki z zastosowaniem STATISTICA PL na przykładach z medycyny. Kraków: StatSoft; 2006.

\section{Correspondence address}

Marcin Olajossy, II Department of Psychiatry and Psychiatric Rehabilitation, Medical University of Lublin, ul. Głuska 1, 20-439 Lublin

Otrzymano: 24.04.2016

Zrecenzowano: 08.05.2016

Przyjęto do druku: 15.05.2016 